\title{
A new 2-alkylhydroquinone glucoside from Phagnalon saxatile (L.) Cass.
}

Hanene Cherchar ${ }^{\mathrm{a}}$, Meriem Lehbili ${ }^{\mathrm{a}}$, Djemaa Berrehal ${ }^{\mathrm{a}^{*}}$, Hamid Morjani $^{\mathrm{c}}$, Abdulmagid Alabdul Magid $^{\mathrm{b}}$, Laurence Voutquenne-Nazabadioko ${ }^{\mathrm{b}}$, Ahmed Kabouche $^{\mathrm{a}}$ and Zahia Kabouche ${ }^{\mathrm{a}^{*}}$

${ }^{a}$ Université des frères Mentouri-Constantine, Département de chimie, Laboratoire d'Obtention des Substances Thérapeutiques (LOST), Campus Chaabet-Ersas, 25000 Constantine, Algeria;

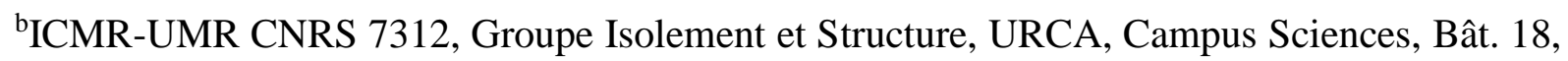
BP 1039, 51687 Reims Cedex 2, France; 'MEDyC UMR CNRS 7369, URCA, Faculté de Pharmacie, SFR CAP Santé, 1, rue du Maréchal-Juin, 51096 Reims, France

*Corresponding author: Prof. Zahia KABOUCHE

E-mail: zahiakabouche@gmail.com

Tel/fax: 213-31811100 


\begin{abstract}
A new 2-alkylhydroquinone glucoside, 1-O- $\beta$-D-glucopyranosyl-1,4-dihydroxy-2-((E) 2-oxo3-butenyl)benzene (1), in addition to nine known compounds were isolated from the aerial parts of Phagnalon saxatile (L.) Cass. (Asteraceae). Their structures were identified based on spectroscopic methods including 1D and 2D NMR, mass spectrometry (HR-ESI-MS), UV spectral analyses and by comparison with literature data. The cytotoxic activity of three isolated compounds (1-3) was evaluated against fibrosarcoma (HT1080), human lung cancer (A549) and breast cancer (MCF7) cell lines.
\end{abstract}

Keywords: Phagnalon saxatile (L.) Cass.; Asteraceae; alkylhydroquinone glucoside; cytotoxic activity. 


\section{Introduction}

Phagnalon is one of the Euro-Mediterranean genuses, which is represented by about 36 species distributed throughout Northeastern tropical Africa, the Macaronesian region, the Mediterranean basin, the Irano-Turanian and the Saharo-Arabian regions, but its greatest diversity is found in the Arabian Peninsula (Qaiser et al. 2003). Phagnalon species are used in folk medicine as antiallergic, antioxidant, anti-inflammatory and in the treatment of asthma and headache (Ali-Shtayeh et al. 1998; Conforti et al. 2010; Haddouchi et al. 2014). Many reports have shown that Phagnalon species possess biological properties, e.g., hypertensive, anticholinesterase, antimicrobial, antibacterial, antiproliferative and cytotoxic activities (Hausen et al. 1977; Conforti et al. 2010; Wamidh et al. 2010a; Wamidh et al. 2010b). The phytochemistry of the genus Phagnalon is not well known, only 4 of the 36 recorded Phagnalon species have been subjected to phytochemical examination. It appears that flavones glycosides (apigenin and its derivative and luteolin and its derivatives), prenylhydroquinone glycosides and dicaffeoylquinic acid derivatives are characteristics to this genus (Dolci et al. 1982; Góngora et al. 2001, 2002; Conforti et al. 2010). In addition, terpenoids were reported from Phagnalon species (Bicchi et al. 1979; Epifano et al. 2002). Phagnalon saxatile (L.) Cass. growing in Algeria is a fairly common Mediterranean plant, which grows on walls and rocks, but also in rocky lawns. The leaves, very narrow, are green on the upper side and cottony underneath. The heads are solitary at the extremity of the branches. The external bracts are bent outwards (Quezel \& Santa 1963). The essential oil of the aerial parts of the plant was found to contain sesquiterpenes, fatty acids and waxes (Conforti et al. 2010). In addition, 3,3dimethylallyl-p-benzoquinone and flavonoids such as apigenin, apigenin-7-glucoside and luteolin were reported from this plant but phytochemical data are incomplete and pharmacological information on the plant and its metabolites are lacking (Conforti et al. 2010). In the present work, a new 2-alkylhydroquinone glucoside (1), along with nine known compounds (2-10), was isolated from the air-dried extracts of $P$. saxatile. The cytotoxic activity of the three most original compounds (1-3) was tested against HT1080, A549 and MCF7 cells lines.

\section{Results and Discussion}

The EtOAc and the $n$ - $\mathrm{BuOH}$ extracts of the aerial parts of $P$. saxatile (L) Cass. were subjected to combined chromatographic methods to obtain a new 2-alkylhydroquinone glucoside (1) (Fig. 1), in addition to nine known compounds (2-10) (see Figure S1). They include potassium 4hydroxy-3-methoxybenzoic acid methyl ester-5-sulfate (2) (Benmerache et al. 2017), 
hydroquinone glucoside, 1-O- $\beta$-D-glucopyranosyl-1,4-dihydroxy-2-(3',3'-dimethylallyl)benzene (3) (Góngora et al. 2001), six flavonoids, apigenin 7- $O-\beta$-D-glucopyranoside (4), luteolin-4'-O- $\beta$-D-glucopyranoside (5), luteolin-7-O- $\beta$-D-glucopyranoside $\quad$ (6), 3'methoxyluteolin (7), apigenin (8) and luteolin (9) (Dommisse et al. 1986; Agrawal et al. 1989; Nacer et al. 2006; Touafek et al. 2011), and dicaffeoylquinic acid derivative, 3,5-di-Ocaffeoylquinic acid methyl ester (10) (Timmermann et al. 1983). The isolated compounds were identified by analysis of ${ }^{1} \mathrm{H}$ and ${ }^{13} \mathrm{C}$ NMR spectra along with 2D experiments (COSY, HMBC, HSQC, NOESY and HMBC) and by comparison with those reported in the literature.

Compound 1 displayed a pseudo-molecular ion peak at $\mathrm{m} / \mathrm{z} 363.1053[\mathrm{M}+\mathrm{Na}]^{+}$(calcd for $\mathrm{C}_{16} \mathrm{H}_{20} \mathrm{O}_{8} \mathrm{Na}$, 363.1056) indicating its molecular formula to be $\mathrm{C}_{16} \mathrm{H}_{20} \mathrm{O}_{8}$. The ${ }^{1} \mathrm{H} \mathrm{NMR}$ spectrum displayed the signal pattern typical of an alkylhydroquinone (David et al. 1998; Góngora et al. 2001): three aromatic protons (H-3, H-5, and H-6) exhibited an ABX system $\left(\delta_{\mathrm{H}}\right.$ $7.04,6.81$, and 7.11, respectively), two olefinic protons conjugate to a carbonyl group at $\delta_{\mathrm{H}}$ 6.61 and 7.99, and one methyl group at $\delta_{\mathrm{H}} 2.33$ arising from a prenyl residue. This was confirmed by analysis of the ${ }^{13} \mathrm{C}$ NMR spectrum, which showed six aromatic signals, two of them were oxygenated $\left(\delta_{\mathrm{C}} 149.7\right.$ and 153.2$)$, two olefinic carbons $\left(\delta_{\mathrm{C}} 128.1\right.$ and 138.1), one methyl $\left(\delta_{\mathrm{C}} 27.4\right)$ and one carbonyl carbon $\left(\delta_{\mathrm{C}} 199.1\right)$. The analysis of COSY spectrum showed correlation between the two olefinic protons with the coupling constant of $16.6 \mathrm{~Hz}$, indicating a trans configuration of the double bond. In the HMBC spectrum, the carbon of a ketone group at $\delta_{\mathrm{C}} 199.1$ showed correlations with the two olefinic protons $\mathrm{H}-3^{\prime}$ at $\delta_{\mathrm{H}} 6.61$ and $\mathrm{H}-4^{\prime}$ at $\delta_{\mathrm{H}} 7.99$ and the methyl $\mathrm{H}_{3}-1^{\prime}$ at $\delta_{\mathrm{H}} 2.33$. These latter were correlated to the carbon C-3' $\left(\delta_{\mathrm{C}} 128.0\right)$, indicating the presence of a 3-buten-2-one moiety as in a phenyl butanoid glucoside, isolated from Hypochoeris radicata (Ohmura et al. 1989). In addition, an anomeric proton at $\delta_{\mathrm{H}} 4.66$ and six methine protons, appearing between 3.17 and $3.65 \mathrm{ppm}$, were attributed by using the COSY spectrum. Their corresponding carbons identified by the HSQC spectrum are characteristic of a glucopyranose moiety (Ohmura et al. 1989; Góngora et al. 2001) (see Table S1). The HMBC spectrum indicated that the glucose was attached to the hydroxylated carbon C-1 at $\delta_{\mathrm{C}} 149.7$ which correlated to the anomeric proton $\mathrm{H}-1 "$ at $\delta_{\mathrm{H}} 4.66$. This was confirmed by the ROESY correlation between the aromatic proton $\mathrm{H}-6$ and $\mathrm{H}-1$ ". The olefinic proton $\mathrm{H}-$ $4^{\prime}$ at $\delta_{\mathrm{H}} 7.99$ showed HMBC correlations with carbons C-1, C-2 and C-3, indicating that the butanone moiety was attached to the C-2 position. This was confirmed by the HMBC correlation between the quaternary carbon C-2 at $\delta_{\mathrm{C}} 125.6$ to the olefinic proton H-3'. The remaining oxygenated carbon $\mathrm{C}-4\left(\delta_{\mathrm{C}} 153.2\right)$ exhibited a ${ }^{3} J_{\mathrm{C}-\mathrm{H}}$ correlation with the aromatic 
proton H-6 $\left(\delta_{\mathrm{C}}\right.$ 7.11). All these results led us to identify compound 1 as $1-O-\beta$-Dglucopyranosyl-1,4-dihydroxy-2-((E) 2-oxo-3-butenyl)benzene.

The cytotoxic activity of methyl 3,5-dicaffeoylquinate (10) was previously described. It inhibited cell proliferation of HT-29 (Hu et al., 2011) and HeLa cells (Hu et al., 2014), but was inactive on MCF7 and KB cells (Watchara et al., 2016). As flavonoids 4-9 are well-known compounds found in most plant species, we have evaluated only the cytotoxic activity of the three most original compounds from this species. The new alkylhydroquinone glucoside $\mathbf{1}$ and its derivative 3, and the potassium 4-hydroxy-3-methoxybenzoic acid methyl ester-5-sulfate (2), previously isolated in our laboratory for the first time (Benmerache et al. 2017), were tested for their cytotoxic activity against HT1080, MCF7 and A549 cell lines (Table S2). Compound 3, showed moderate cytotoxic activity against HT1080, MCF7 and K562 cells with $\mathrm{IC}_{50}$ values of 33.2, 37.0 and $77.0 \mu \mathrm{M}$, respectively. Compounds $\mathbf{1}$ and $\mathbf{2}$ showed also moderate cytotoxicity on HT1080 cells only with $\mathrm{IC}_{50}$ values of 48.0 and $44.0 \mu \mathrm{M}$, respectively. The butanone side chain in compound $\mathbf{1}$ seems to reduce the cytotoxic activity compared to the isoprenyl side chain in compound 3.

\section{Experimental}

\subsection{General experimental procedures}

NMR spectra were carried in MeOH- $d_{4}$ and DMSO on Bruker Avance DRX III 500 instruments. HR-ESI-MS experiment was performed using a Micromass Q-TOF micro instrument. Compounds were observed under UV light at 254 and $365 \mathrm{~nm}$ or visualized by spraying the dried plates with $50 \% \mathrm{H}_{2} \mathrm{SO}_{4}$, followed by heating. $\mathrm{CC}$ was carried out on Kieselgel 60 (63-200 mesh) or polyamid SC6 Merck.

\subsection{Plant material}

The aerial parts of Phagnalon saxatile (L.) Cass. were collected in April 2013 from Constantine (Eastern Algerian). The plant was authenticated by Mr. Kamel Kabouche. A voucher specimen (LOST Phs04/13) was deposited at the herbarium of the Laboratory of Therapeutic Substances (LOST), faculty of Sciences, University of Constantine, Algeria.

\subsection{Extraction and isolation}

Air-dried aerial part of Phagnalon saxatile (L.) Cass. (1200 g) were extracted with the mixture of ethanol and water (8:2) for $48 \mathrm{~h}$, at room temperature. The solvent was removed under 
reduced pressure. The $80 \% \mathrm{EtOH}$ extract was suspended in water and fractionated with solvents of increasing polarity to obtain petroleum ether (1.05 g), $\mathrm{CHCl}_{3}(1.86 \mathrm{~g})$, EtOAc (11.32 g) and $n$ - $\mathrm{BuOH}(25.31 \mathrm{~g})$ fractions. The $n-\mathrm{BuOH}$ and EtOAc fractions were combined $(20 \mathrm{~g})$ and column chromatographed on polyamid SC6 eluting with a gradient of toluene-MeOH with increasing polarity to yield 20 fractions (F1-F20 respectively). Compounds 7 (20 mg), 4 (16 $\mathrm{mg}), 5(12.5 \mathrm{mg})$ and $2(15 \mathrm{mg})$ were precipitated from fractions F10, F14, F15 and F17, respectively. Fraction F12 (673 mg) was separated on silica gel column chromatography eluted with $\mathrm{CHCl}_{3}-\mathrm{MeOH}$ with increasing polarity to afford compounds $1(7 \mathrm{mg}), \mathbf{3}(9 \mathrm{mg})$, and $\mathbf{8}(10$ mg). Fraction F16 (915 mg) was further subjected to silica gel column chromatography eluted with $\mathrm{CHCl}_{3}-\mathrm{MeOH}$ with increasing polarity to give compounds $\mathbf{6}(4.5 \mathrm{mg}), \mathbf{9}(4 \mathrm{mg})$ and 10 (6 $\mathrm{mg})$.

\subsubsection{1-O-ß-D-glucopyranosyl-1,4-dihydroxy-2-((E) 2-oxo-3-butenyl)benzene(1) was} obtained as a white amorphous solid, $[\alpha]_{\mathrm{D}}{ }^{20}+48^{\circ}(c 0.58, \mathrm{MeOH}),{ }^{1} \mathrm{H}$ NMR $(600 \mathrm{MHz}, \mathrm{DMSO})$ : $\delta_{\mathrm{H}} 7.04(\mathrm{~d}, J=2.8 \mathrm{~Hz}, \mathrm{H}-3), 6.81(\mathrm{dd}, J=8.9,2.8 \mathrm{~Hz}, \mathrm{H}-5), 7.11$ (d, $\left.J=8.9 \mathrm{~Hz}, \mathrm{H}-6\right), 6.61$ (d, $J=16.6$ Hz, H-3'), 7.99 (d, J = 16.6 Hz, H-4'), 2.33 (s, 3H-1'), 4.66 (d, J = 7.5 Hz, H-1"), 3.29 (m, H-2"), 3.25 (t, $J=8.3 \mathrm{~Hz}, \mathrm{H}-3 "), 3.17$ (t, $J=8.9 \mathrm{~Hz}, \mathrm{H}-4 "), 3.24$ (m, H-5), 3.48 (m, H-6"a), 3.69 (brd, $J=11.6 \mathrm{~Hz}$, H-6"b), ${ }^{13}$ C NMR (150 MHz, DMSO): $\delta \mathrm{c} 149.7$ (C-1), 125.6 (C-2), 112.8 (C-3), 153.2 (C-4), 119.3 (C5), 119.6 (C-6), 27.4 (C-1'), 199.1 (C-2'), 128.0 (C-3'), 138.7 (C-4'), 102.9 (C-1"), 73.9 (C-2"), 77.0 (C3"), 70.2 (C-4"), 77.5 (C-5"), 61.3 (C-6"). HR-ESI-MS [M+Na] $]^{+} m / z 363.1053$ (calcd for $\left.\mathrm{C}_{16} \mathrm{H}_{20} \mathrm{O}_{8} \mathrm{Na}, 363.1056\right)$.

\subsection{Cell proliferation assay}

The fibrosarcoma cells HT1080 were cultured in Minimum Essential Media (MEM), while human lung cancer cells A549 and MCF7 were cultured in Dulbecco's Modified Eagle's Medium (DMEM), supplemented with 10\% fetal bovine serum (FBS) and 1\% Penicillin Streptomycin (PS) at $37{ }^{\circ} \mathrm{C}$ with $5 \% \mathrm{CO}_{2}$ and harvested every three days for maintenance. Compounds 1-3 were dissolved in DMSO to be tested.

HT1080, A549 and MCF7 cells were plated at a density of $10^{4}$ cells/mL in 24-well plates, in fully humidified incubator $\left(5 \% \mathrm{CO}_{2}, 37^{\circ} \mathrm{C}\right)$. After $24 \mathrm{~h}$, the culture medium was discarded and cells were treated with the compounds in a fresh culture medium at various concentrations for 72h. Therefore, the cells were washed once with $1 \mathrm{~mL}$ of D-PBS and then detached with $0.2 \%$ Trypsin/EDTA. Cell counting was carried out on a KOVA® slide and with a phase contrast microscope as indicated by the manufacturer's. Camptothecin and doxorubicin were used as 
positive control. The results of these assays were used to determine the $\mathrm{IC}_{50}$ as the concentration of each compound which induced 50\% inhibition of cell growth.

\section{Conclusions}

In summary, one new 2-alkylhydroquinone glucoside, together with nine known compounds, including six flavonoids, were isolated from the aerial parts of Phagnalon saxatile(L.) Cass. Four from the six known flavonoids: apigenin (8), apigenin 7-O- $\beta$-D-glucopyranoside (4), luteolin (9), and luteolin-4'-O- $\beta$-D-glucopyranoside (5) were previously isolated from $P$. saxatile (L.) Cass. (Conforti et al. 2010). Luteolin-7-O- $\beta$-D-glucopyranoside (6) was previously reported from $P$. rupestre (Góngora et al. 2002), and 3'-methoxyluteolin (7) was isolated for the first time from the Phagnalon genus. The prenylhydroquinone 1-O- $\beta$-D-glucopyranosyl-1,4dihydroxy-2-(3',3'-dimethylallyl)benzene (3) was isolated from P. rupestre (Góngora et al. 2001), and 3,5-di-O-caffeoylquinic acid methyl ester (10) was reported from $P$. rupestre (Góngora et al. 2002) and P. saxatile (L.) Cass. (Conforti et al. 2010). Potassium 4-hydroxy-3methoxybenzoic acid methyl ester-5-sulfate was isolated for the first time from the Phagnalon genus.

Compound 3, showed a moderate cytotoxic activity against HT1080, MCF7 and K562 whereas compounds 1 and $\mathbf{2}$ showed also moderate cytotoxicity on HT1080 cell line only.

\section{Acknowledgments}

The authors are grateful to DGRSDT-MESRS (Algeria), for financial support and the Groupe Isolement et Structure of the Institut de Chimie Moleculaire de Reims (France) for technical help and registering of NMR data and MS.

\section{Supporting Information}

Cytotoxic activity of compounds 1-3, figure $\mathrm{S} 1$ and HR-ESI-MS, ${ }^{1} \mathrm{H}$ and ${ }^{13} \mathrm{C}$ NMR, COSY, HMBC, HSQC and NOESY spectra for compound 1.

\section{References}

Agrawal PK, Bansal MC. 1989. Flavonoid glycosides. In: Agrawal, P.K. (Ed.), Carbon-13 NMR of flavonoids. Elsevier, Amsterdam, pp. 283-364.

Ali-Shtayeh MS, YaghmourMS. 1998. Antimicrobial activity of 20 plants used in folkloric medicine in the Palestinian area. J Ethnopharmacol. 60:265-271. 
Benmerache A, Benteldjoune M, Alabdul Magid A, Abedini A, Berrehal D, Kabouche A, C. Gangloff S, Voutquenne-Nazabadioko L, Kabouche Z. 2017.Chemical composition, antioxidant and antibacterial activities of Tamarix balansae J. Gay aerial parts. Nat ProdRes. http://dx.doi.org/10.1080/14786419.2017.1299729.

Bicchi C, Frattini C, Nano GM.1979. Hexahydrofarnesyl acetone from Phagnalon rupestre. Relata Tech. 11:64.

Conforti F, Rigano D, Formisano C, Bruno M, Loizzo MR, Menichini F, Senatore F. 2010. Metabolite profile and in vitro activities of Phagnalon saxatile (L.) Cass, relevant to treatment of Alzheimer's disease. J Enzyme Inhib Med Chem. 25:97-104.

David JM, Chàvez JP, Chai HB, Pezzuto JM, Cordell GA. 1998. Two new cytotoxic compounds from Tapirira guianensis. J Nat Prod. 61:287-289.

Dolci M, Tira S. 1982. Flavonoids of Gnaphalieae: Phagnalon species. Atti Accad Naz Lincei Cl Sci Fis Mat Natur Rend. 116:315-318.

Dommisse RA, Van Hoof L, Vlietinck AJ. 1986. Structural analysis of phenolic glucosides from Salicaceae by NMR spectroscopy. Phytochemistry. 25:1201-1204.

Epifano F, Marcotullio MC, Menghini L. 2002. Constituents of Phagnalon sordidum. J Chem Nat Compd. 38:204-205.

Góngora L, Giner RM, Máñez S, Recio MC, Ríos JL. 2001. New prenylhydroquinone glycosides from Phagnalon rupestre. J Nat Prod. 64:1111-1113.

Góngora L, Máñez S, GinerRM, Recio MC, Gray AI, Rios JL. 2002. Phenolic glycosides from Phagnalon rupestre. Phytochemistry. 59:857-860.

Góngora L, Máñez S, GinerRM, Recio MC, Rios JL. 2002. Phagnalon rupestre as a source of compounds active on contact hypersensitivity. Planta Med. 68:561-564.

Haddouchi F, Chaouche TM, Ksouri R, Medini F, Sekkal FZ, Benmansour A. 2014. Antioxidant activity profiling by spectrophotometric methods of aqueous methanolic extracts of Helichrysum stoechas subsp. rupestre and Phagnalon saxatile subsp. Saxatile. Chinese J Nat Med. 12:415-422.

Hausen BM, Schulz KH. 1977. On sensitizing capacity of naturally occurring quinones3. New contact allergen (2-dimethylallyl-1,4-benzoquinone) from Phagnalon. Planta Med. 32: 287-296.

Hu T, He X-W, Jiang J-G. 2014. Functional Analyses on Antioxidant, Anti-inflammatory, and Antiproliferative Effects of Extracts and Compounds from Ilex latifolia Thunb., a Chinese Bitter Tea. J. Agri. Food Chem. 62: 8608-8615. 
Hu W, Shen T, Wang MH. 2011. Cell cycle arrest and apoptosis induced by methyl 3,5dicaffeoyl quinate in human colon cancer cells: involvement of the PI3K/Aktand MAP kinase pathways. Chem. Biol. Interact. 194: 48-57

Nacer A, Bernard A, Boustie J, Touzani R, Kabouche Z. 2006. Aglycone flavonoids of Centaurea tougourensis from Algeria. Chem Nat Compd. 42:190-191.

Ohmura K, Miyase T, Ueno A. 1989. Sesquiterpene glucosides and aphenylbutanoid glycoside from Hyprochoeris radicata. Phytochemistry. 28:1919-1924.

Qaiser M, Abid R. 2003. Phagnalon Cass. In: Ali, S.I. \& Qaiser, M. (Eds.). Flora of Pakistan. Asteraceae (II) Inuleae, Plucheeae \& Gnaphalieae, vol. 210. Department of Botany, University of Karachi and Missouri Press, Missouri Botanical Garden, St. Louis.

Quezel P, Santa S. 1962-1963. Nouvelle Flore de l'Algérie et des régions désertiques méridionales. Vol. 1-2. Ed. CNRS, Paris France.

Timmermann BN, Hoffmann JJ. 1983. Constituants of Chrysothamnus paniculatus 3: 3,4,5tricaffeoylquinic acid (a new shikimate prearomatic) and 3,4-, 3,5- and 4,5dicaffeoylquinic acids. J Nat Prod. 46:365-368.

Touafek O, Kabouche Z, Brouard I, Bermejo JB. 2011. Flavonoids of Campanula alata Desf. and their antioxidant activity. Chem Nat Compd. 45:968-969.

Wamidh HT, Mahasneh AM. 2010a. Antimicrobial, cytotoxicity and phytochemical screening of Jordanian plants used in traditional medicine. Molecules. 15:1811-1824.

Wamidh HT, Mahasneh AM. 2010b. Antiproliferative activity of plant extracts used against cancer in traditional medicine. Sci Pharm. 78:33-45.

Watchara S, Ratsami L, Somdej K, Kwanjai K. 2016. Cytotoxic and antimalarial constituents from aerial parts of Sphaeranthus indicus. Phytochem. Lett.s 17:278-281. 